\title{
AUTONOMOUS CONCEPTS AND STATUS QUO METHOD: QUEST FOR COHERENT PROTECTION OF HUMAN RIGHTS BEFORE EUROPEAN SUPRANATIONAL COURTS ${ }^{* * *}$
}

\begin{abstract}
The accession of the European Union to the European Convention on Human Rights is currently being renegotiated, but this remains a rocky and time-consuming process. Mostly relying on doctrinal method, the authors examine various methods advocated in legal theory as a means to ensure a coherent protection of human rights in Europe in the absence of an institutional agreement. The authors focus their attention on the further development of autonomous concepts in the case law of two the European supranational courts as a prerequisite for successful application of the status quo method. The principle of ne bis in idem is selected as a case in point. Finally, authors formulate proposals for approaches regarding autonomous concepts to be utilized by the Court of Justice and the European Court of Human Rights.

Keywords: European Union, European Convention on Human Rights, supranational courts, autonomous concepts, ne bis in idem.
\end{abstract}

\section{Introduction}

In the wake of the 70th anniversary of the European Convention on Human Rights (hereinafter: ECHR), the issue of the accession of the European Union (hereinafter: EU) to the ECHR gained new momentum and renegotiation of the agreement is back on the table (European Parliament, 2020, p. 1). Namely, in September 2020, the Council of Europe (hereinafter: CoE) and the European Commission issued a joint statement pertaining to the resumption of negotiations. The statement points out that the accession of the EU to the ECHR "will be an important milestone in the protection of human rights and fundamental freedoms across Europe", as well as that accession will inter alia help to guarantee "coherence and consistency" between EU law and the system of the ECHR (European Commission, 2020, p. 1).

\footnotetext{
* PhD, Senior Research Fellow, Institute of Comparative Law, Belgrade, Serbia, e-mail: v.coric@iup.rs

${ }^{* *} \mathrm{PhD}$, Research Fellow, Institute of Comparative Law, Belgrade, Serbia, e-mail: a.bojovic@iup.rs, ORCID ID: 0000-0002-3746-5747

${ }^{* * *}$ This paper was written as a part of the Research Programme of the Institute of Comparative Law for 2020, which is supported by the Serbian Ministry of Education, Science and Technological Development.
} 
The statement itself should not be read as a political, but as a policy one, as the EU has been preparing for the launch of the process for some time. More than a year ago, the European Commission prepared a 'Staff Working Document' - a comprehensive outline of the proposed EU position for the re-negotiation of the draft accession agreement of the EU in line with the findings of Opinion 2/13 of 2014 of the Court of Justice of the European Union (hereinafter: CJEU) (Council of the European Union, 2019, p. 3). ${ }^{1}$ In a similar vein, after having received a written contribution from the European Commission, in October 2019, the Council reaffirmed its commitment to the accession and agreed to supplementary negotiating directives as to enable a resumption of negotiations with the CoE (European Parliament, 2020, p. 1).

Once the Secretary General of the CoE was informed that the EU is ready and willing to proceed with the negotiations on its accession to the ECHR, she pointed that she would make proposals on the format in which these negotiations could be conducted. The critical point in time was approval of the Ministers' Deputies of the continuation of the work of the Steering Committee for Human Rights (hereinafter: $\mathrm{CDDH}$ ) in co-operation with the representatives of the $\mathrm{EU}$, through the $\mathrm{CDDH}$ ad hoc negotiation group (hereinafter: $47+1$ Group) on the basis of the work already conducted on the accession, in January 2020 (also see: Steering Committee for Human Rights (CDDH), 2010). Subsequent to that, two formal meetings and one informal meeting of the $47+1$ Group were held on the accession of the EU to the ECHR, while the next one is scheduled for February 2021. The frequency of the meetings of the $47+1$ Group shows the level of the renegotiation endeavours.

However, it has been rightly argued for a long time in the legal theory that regardless of all the invested efforts, the road to accession remains "rocky" (Murphy, 2013, p. 1) and "long and winding" (Buyse, 2013, p. 1). Namely, the future negotiated draft agreement will have to be ratified by all EU Member States "in accordance with their respective constitutional requirements" (Article 218 (8) of the Treaty on the Functioning of the EU (hereinafter: TFEU) as well as by all State Parties to the ECHR. In addition, European Parliament's consent to the accession agreement is required under Article 218(6) of the TFEU (European Parliament, 2020, p. 1).

This unambiguously shows that the accession of the EU to the ECHR is going to be a time-consuming process. Therefore, short-term solutions should be applied as to reduce the adverse effects of a prolonged non-accession of the EU to the ECHR. While most legal scholars advocate for the establishment of an institutional link between the judicial system of the ECHR and the EU legal order through the accession agreement, as the optimal method for providing the coherent and effective human rights protection before supranational courts in Europe, it is desirable to consider the applicability of other available solutions, which can contribute to enhanced coherence of the fundamental rights protection in Europe. Therefore, the next section of this paper will examine other methods advocated in legal theory for ensuring the coherent and effective protection of human

\footnotetext{
${ }^{1}$ On 18 December 2014, the CJEU delivered its Opinion 2/13 on the compatibility with EU law of the draft agreement for EU accession to the ECHR concluding that the drafted accession agreement is not compatible with EU law. See Douglas-Scott, 2014, and Matić Bošković, 2020, p. 31.
} 
rights before the CJEU and the European Court of Human Rights (hereinafter: ECtHR), while not requiring the creation of an institutionalized arrangement between the CJEU and the ECtHR. The analysis is aimed to determine whether those methods are capable to enhance coherence and effectiveness of the human rights protection in Europe. In the subsequent section, the doctrine of autonomous concepts will be explored as to determine whether and how it should be upgraded as to be more beneficial for the development of coherent and effective protection of human rights before the supranational courts in Europe. In that context, the paper will particularly examine only one of the numerous autonomous concepts, which have been developed by the two courts: the principle of ne bis idem. The autonomous concepts of ne bis in idem was selected as case in point, as the most recent case law of both European supranational courts provides some relevant insights and development in the arena of their harmonizing effects. The concluding section of the paper attempts to come up with the proposals for improvement of the approaches of the ECtHR and CJEU in developing autonomous concepts in order to enhance the coherence and efficiency of human rights protection in Europe even before the accession takes place.

\section{Methods for the establishment of a coherent and effective human protection before supranational courts in Europe advocated in legal doctrine}

The various proposed (and to an extent, utilized) solutions for the creation of coherent and effective system of human rights protection before supranational courts in Europe can be systematized in five categories. These are, inter alia: the method of adoption of a separate EU catalogue of fundamental rights, the method of amending the ECHR, the method of establishing an institutional link between two courts, the method of de facto accession of the EU to the ECHR and the method of continuation of the status quo (Ćorić Erić, 2013, p. 9). Most of these methods were already tested in practice and their effects were comprehensively examined in legal doctrine. As it was explained earlier, the accession process is expected to be time-consuming and "winding" and therefore it is too early to assess its effects on the coherence and effectiveness of human rights protection in Europe.

The Charter of Fundamental Rights of the EU (hereinafter: EU Charter), which is considered as outcome of the application of the aforementioned method pertaining to the adoption of a separate EU catalogue of fundamental rights did not yield expected results in terms of ensuring coherence of the protection of human rights in Europe. ${ }^{2}$ The EU Charter was initially praised by some scholars as a tool which is ensuring coherence between the case law of two supranational courts as it includes two norms (Articles 52(3) and 53 of the EU Charter) that provide interpretative guidance with regards to the interaction between the EU Charter and the ECHR (Lenaerts, 2018, p. 4). According to those provisions, the EU Charter's rights that correspond to ECHR's rights should be interpreted in the same way as those ECHR rights. In addition, once the correspondence between two rights is established, the CJEU will strive to ensure that the EU Charter is interpreted so as to provide, at the very least, a level of protection that corresponds to that of the ECHR, as interpreted by the ECHR

\footnotetext{
${ }^{2}$ More on the history of the EU Charter see, inter alia, Ćeranić, 2009, pp. 16-17.
} 
(Craig, 2013, pp. 1145-1146). Despite those provisions, the EU Charter differs from the ECHR, as certain rights are worded differently than the corresponding rights in the ECHR, while it contains certain rights and freedoms that are not covered by the ECHR. Those differences, coupled with the fact that in the course of the last decade the CJEU has become more focused on the EU Charter as its own "human rights catalogue", in the literature referred to as the "EU Charter-centrism", have negatively affected the coherence between case-law of the two courts (Glas \& Krommendijk, 2017, p. 574; Kuijer, 2020, p. 1001). ${ }^{3}$

Similar to that, the method of amending the ECHR has not given any harmonizing effect through its application in practice. The Protocol 16 seems promising in that regard. One of its key novelties, which is beneficial for the strengthening coherence of human rights protection in Europe, relates to the establishment of a new procedure under which domestic courts or tribunals will be able to request an advisory opinion from the ECtHR on the fundamental issues pertaining to the interpretation and application of the rights and freedoms contained in the ECHR or its additional protocols. However, it can come into play with regards to the EU only if the EU ratifies it once it accedes to the ECHR. ${ }^{4}$

The application of the method of de facto accession of the EU to the ECHR, advocated by some scholars, also gave very limited results in practice. Through the progressive role of both courts the area of overlapping jurisdictions of the two supranational courts has been extended over the time. That additionally increased the risk of a potential normative conflicts. Kuijer (2020) rightly argued that the ECtHR mostly followed the approach of "professional courtesy" introduced in its Bosphorus ruling (Bosphorus Hava Yollari Turizm ve Ticaret AS v. Ireland referred by Kuijer, 2018, p. 8). By doing so, it exercised a sort of judicial restraint towards the adjudication of the CJEU. That "professional courtesy" approach has undermined the application of the method of de facto accession, as it disabled the ECtHR from reviewing the cases which are strongly linked to the EU legal order. Therefore, the method of de facto accession did not find its full application in practice and therefore its potential effects on the coherence of human rights protection in Europe remained uncertain. Certain opponents of the method of de facto accession rightly argued that the proposed idea, which is based on the court activism, was not beneficial for achieving sufficient level of coherence due to the lack of guarantees that the courts will not rapidly nor radically change their case-law (Van den Berghe, 2010, p. 154; Kuijer, 2020, pp. 1004-1005).

Finally, a group of authors was in favour of maintaining the jurisdictionally complex status quo (Douglas-Scott, 2006, p. 665; Toth, 1997, p. 492). In that context, Weiler and Alston (1999) referred to the method of the maintaining of status quo as to "normative supranationalism". According to them, once the political processes stall, the courts can proceed with integration (Weiler \& Alston, 1999, p. 53). This method was perceived by its supporters as capable to contribute to mutual dialogue and cooperation between judges

\footnotetext{
${ }^{3}$ Witte (2018) underlines that the ECHR and the case law of the Strasbourg Court are still present in the case law of the CJEU, but they are used more sparingly and selectively than they were before the entry of force of the Treaty of Lisbon. In addition, according to O' Leary $(2018$, p. 4) it is estimated that one out of every ten cases before the CJEU now reference the Charter, and many of its most significant judgments in recent years have had an important fundamental rights dimension.
}

${ }^{4}$ Thus far only 15 countries ratified it. 
of the two courts leading to more integrated and harmonized human rights' approach in Europe (Defeis, 2001, p. 303). In addition, it was praised for its flexibility, while criticized for the limited effects it had on the consistency of case-law of the two courts. Its inability to reduce the given inconsistencies was explained by the lack of an explicit hierarchal relationship between the courts (Kuijer, 2020, p. 1002).

However, it seems that even in the absence of the institutionalized hierarchical link, there is room for improvement of the performance of both supranational courts as to achieve more harmonized human rights approach to Europe through the stronger recourse to the doctrine of autonomous concepts while applying the method of continuation of status quo. The following section will examine the potential of this doctrine to improve the performance of both courts in achieving coherent human rights protection in Europe.

\section{Role of autonomous concepts in the creation of coherent and effective system of human rights protection in Europe}

The doctrine of autonomous concepts was initially developed by the ECtHR in early 1970s, while ten years later the European Court of Justice, as the CJEU was officially called at the time, also started to refer to the notion of autonomous concepts in its jurisprudence (Lenaerts \& Gutiérrez-Fons, 2013, p. 7; Ćeranić, 2017, pp. 89-102).

In a nutshell, this doctrine implies that autonomous concepts of the ECHR's and the EU law shall be interpreted independently from the meaning which equivalent concepts have in domestic law. This doctrine was developed by the ECtHR so as to prevent contracting states from violating the guarantees of the ECHR, by giving its own, narrow interpretation of the terms contained in the ECHR. It is noteworthy that the doctrine of autonomous concepts is not specific only of European supranational courts. Instead, it is in line with the broader approach followed in international law, according to which any state cannot rely on its own law as an excuse for failure to comply with its international obligations (Bjorge, 2015, pp. 201-203).

In legal theory, different rationales behind the doctrine of autonomous concepts were raised. For instance, Mahoney claimed that the development of the autonomous concepts in the case law of the ECtHR is attributable to "the open textured language and the structure of the convention" which leaves the court significant opportunities for different interpretations (Mahoney, 1998, p. 2). In addition, it was argued that, through the development of autonomous concepts, integration among the EU member states was fostered (Milčiuviene, 2019, p. 101). In that context, Mitsilegas points that the autonomous concepts "achieve effectiveness by managing legal diversity to create a level playing field" (Mitsilegas, 2016, p. 127). Furthermore, it was claimed that it would not be possible to avoid the development of autonomous concepts, since different member states do not share common criteria which provide for the uniform interpretation and application of the ECHR law (Milčiuvienè, 2019, p. 101). In that light, Lenaerts \& Gutiérrez-Fons, specify an extensive body of case-law where the CJEU recourse to the autonomous concepts is based on the need for a uniform application of EU law and the principle of equality (Lenaerts \& Gutiérrez-Fons, 2013, p. 13). 
All those explanations of the doctrine of autonomous concepts are sound and well grounded. However, it seems that, in formulating the autonomous concepts, both courts failed to take into account the need for a more coherent approach to the protection of human rights between the ECtHR and CJEU. By doing so, both courts are distracted from achieving the desired effectiveness of the autonomous concepts. It appears that both courts have been focused on preserving the aim and objective of the single instrument at stake: for the ECtHR that was the ECHR, while for the CJEU that was the specific instrument of the EU law. Therefore, it seems the CJEU should give more attention to the need to preserve the aim and objective of the ECHR in formulating its own autonomous concepts. Although both the ECtHR and CJEU, through their case law, have developed a broad spectrum of autonomous concepts, this paper will focus only on the examination of one of them: the principle of ne bis idem. That principle was selected because the most recent case law of both European supranational courts provides some interesting insights in terms of harmonizing effects of autonomous concepts.

\section{Ne bis in idem and cross-fertilization of autonomous concepts in the light of the most recent case-law}

The recent case-law of the CJEU and the ECtHR with regards to the ne bis in idem principle is a case in point with regards to the need for further convergence in the jurisprudence of the two courts and a more harmonious interpretation of the two seminal human rights' instruments - namely the ECHR and the EU Charter within the two supranational systems. ${ }^{5}$

Until recently, the jurisprudence of the two mentioned courts with regards to the ne bis in idem principle aligned towards a higher level of protection of human rights, as pointed out by Lasagni \& Mirandola (2019). This happened despite the fact that the wordings of the legal instruments guaranteeing the ne bis in idem principle are different, and that the principle had a wider scope of application within the EU due to being enshrined not only in the EU Charter, but also in the Convention on Implementation of Schengen Agreement, whereby it applies also to transnational setting (Lasagni \& Mirandola, 2018; Matić Bošković \& Kostić, 2020, p. 70). While differing in scope and wording, both the ECHR and the EU Charter require the following to be in place in order for the ne bis in idem principle to apply: two sets of procedures of criminal nature, concerning the same facts, initiated against the same offender, where a final decision has been passed in one of the said proceedings. ${ }^{6}$

\footnotetext{
${ }^{5}$ In this context, the principle of harmonious interpretation is understood as the need for the EU law to be consistently interpreted and applied in harmony with international law so as to achieve more coherence, as proposed by Ziegler (2016).

${ }^{6}$ While Lasagni \& Mirandola classify these requirements into four elements: 1) two sets of proceedings of criminal nature (bis), 2) concerning the same facts (idem), 3) against the same offender, and 4) a final decision, Seernels (2019, p. 229) underlines only three elements, as did the ECtHR in paragraph 49 of the judgment in Mihalache v. Romania: the two sets of proceedings must be "criminal" in nature (1); they must concern the same facts (2); and there must be duplication of the proceedings (3).
} 
As Serneels (2019, p. 232) points out, an important example of such alignment can be found in the three rulings the CJEU adopted in 2018, namely in the Menci, Garlsson and Di Puma cases, where the CJEU applied the line of reasoning with regards to one of the key elements of the ne bis in idem principle - the dual proceedings - that was previously applied by the ECtHR in the $A$ and $B v$ Norway case. However, this alignment was an important instance of a reduced scope of human rights protection and the outset of a downward competition in the area of human rights protection.

Namely, in $A$ and $B v$ Norway, the ECtHR redefined the notion of bis and sustained that, in certain cases, a combination of criminal and administrative procedures does not constitute a duplication of proceedings as prescribed by Art. 4 of Protocol No. 7 ECHR (Lasagni \& Mirandola, 2019). ${ }^{7}$ The ECtHR took the position that dual or accumulated punitive administrative and criminal proceedings can be presumed to constitute one integrated whole, provided that there is a "sufficiently close connection in time and substance" between these two proceedings (Serneels 2019, p. 232). This decision was received with severe criticism, spearheaded by the dissenting opinion of judge Pinto de Albuquerque, who claimed that the judgment "opens the door to an unprecedented, Leviathan-like punitive policy based on multiple State-pursued proceedings, strategically connected and put in place in order to achieve the maximum possible repressive effect".

Nonplussed by this argumentation, in the above-mentioned three cases, the CJEU took the position that parallel punitive administrative-criminal proceedings and penalties with regard to the same person and for identical offences in the area of VAT and market abuse can constitute a justified interference with the ne bis in idem right under Article 50 of the EU Charter (Serneels, 2019, p. 232; Matić Bošković \& Kostić 2020, p. 73).

Subsequently to this, the CJEU went on to resort to a different interpretation of the ne bis in idem principle, which this time affected the notion of the „final decision“. Namely, in the Kossowski case the CJEU found that the ne bis in idem principle is not to be applied to the final decision of the authorities in the member states if the criminal investigation of the case was not detailed (Lach, 2017, p. 6). In addition, the CJEU framed its reasoning clearly in the EU context, as an autonomous concept, emphasising in paragraph 47 of the ruling that "the interpretation of the final nature [...] of a decision in criminal proceedings in a Member State must be undertaken in the light not only of the need to ensure the free movement of persons but also of the need to promote the prevention and combating of crime within the area of freedom, security and justice."

This reasoning of the CJEU, surprisingly, has been adopted by the ECtHR in the Mihalache $v$ Romania case. Namely, in this case, the Grand Chamber of the ECtHR had to determine whether a decision of the public prosecutor to discontinue criminal proceedings constituted the notion of "final acquittal or conviction" that would trigger the application of the ne bis in idem principle as enshrined in Article 4, Protocol 7 of the ECHR. ${ }^{8}$ In doing so, the ECtHR firstly explicitly referred to the relevant sources of EU law and the Luxembourg jurisprudence, invoking in detail the reasoning in Kossowski (see paras. 42

\footnotetext{
${ }^{7}$ For an account of the previous ECtHR jurisprudence related to ne bis in idem see: Ilić (2017).

${ }^{8}$ A useful summary is provided at (Lyaskova, 2019).
} 
and 43 of the Michalache judgment). As noted by Serneels (2019, p. 237), the ECtHR then went on to adopt the CJEU interpretation whereby the ne bis in idem applies to decisions that preclude further criminal prosecution, even where such decisions are adopted without the involvement of a court and do not take the form of a judicial decision".' Serneels (2019, p. 239) furthers the argumentation previously put forward by Lock (2016), that such instances of ECtHR's acceptance of the CJEU reasoning constitute legal transplants, which may entail a risk of EU law concepts being transplanted without fully taking into account their wider constitutional context. This position is certainly inspired by the concurring opinion of Judge Pinto de Albuquerque to the judgment in the Mihalache case, where he referred to the wider framework of the area of freedom, security and justice in the EU (including the need to ensure the principles of mutual trust and prevent impunity) as the "intrinsic logic" behind CJEU's reasoning in its case law, as being contrary to the classical pro persona philosophy previously pursued by the ECtHR. ${ }^{10}$ Judge Pinto de Albuquerque went on to state that the ECtHR decision to pursue this approach is an "acritical and precipitate absorption of the Luxembourg case-law on Article 54 CISA, especially Kossowski."

It seems evident that the case-law shows the need for a more coherent, and more focused approach to cross-fertilization of autonomous concepts between the two supranational courts. It is worthwhile recalling the arguments put forward by Lock (2016) with regards to the instances in which ECtHR makes references to EU law sources, including the CJEU jurisprudence. Namely, Lock analysed the challenges that may come into play when the ECtHR bases its findings on EU law in cases against non-EU Member States, some of which have willingly abstained from becoming EU member states. His call upon the ECtHR to adopt a more consistent approach, avoiding copying uncritically EU law approaches therefore seems justified (Lock, 2016) and supportive with the idea of avoiding the downward competition noted in the ne bis in idem case law described above.

Having this in mind, it seems prudent to also call the CJEU to examine more closely whether its case law related to the human rights protection is in line with Article 52, paragraph 3 of the EU Charter, namely to consider whether the protection awarded by the CJEU amounts to the meaning and scope of the rights protected being the same as those laid down by the ECHR. And while the EU Charter allows the EU law to provide more extensive protection of such rights, it can be reasonably argued that it does not call for a convergent lowering of the previously awarded level of protection of human rights by the two supranational courts in favour of efficiency of proceedings and of preventing impunity.

Therefore, a desirable approach in utilising autonomous concepts by the two courts would be twofold: first, it would imply careful consideration of the context of the EU law principles in the jurisprudence of the ECtHR, and second, it would require the CJEU to maintain, at all times, the minimal level of protection of human rights that is enshrined in the ECHR.

\footnotetext{
${ }^{9}$ See paragraph 39 of the Kossowski case and paragraph 95 of the Mihalache judgment.

${ }^{10}$ Paragraphs 33 and 34 of the Concurring opinion of Judge Pinto de Albuquerque

${ }^{11}$ Paragraph 54 of the Concurring opinion of Judge Pinto de Albuquerque.
} 


\section{Conclusion}

The on-going renegotiations of the accession of the EU to the ECHR point to the relevance of achieving coherence and consistency between the EU law and the ECHR system of protection of human rights. In parallel to that, they show that the accession process will continue to be time-consuming and "windy".

The examination of the other available methods which were advocated as capable to enhance the coherence and effectiveness of the European system of human rights protection gave some relevant results. Primarily, it shows that the potential success of the method of continuation of the status quo strongly depends on the approach taken by both supranational courts in developing their autonomous concepts. Thus far, both courts, when formulating the autonomous concepts, failed to sufficiently take into account the need for a more coherent approach to the protection of human rights between the ECtHR and CJEU. Instead, they were mostly focused on preserving the aim and the objective of the legal instrument belonging to their own legal order, while neglecting the other.

The recent case law on ne bis in idem, however, showed that instances of acritical reception of autonomous concepts can have detrimental effects and may result in downward competition, instead providing more effective protection of human rights in Europe. This serves as case in point with regards to the need for further convergence between the autonomous concepts and case-law of the two courts. It reveals that the achieved "harmonizing effect" of their case-laws cannot be necessarily considered as cardinal virtue per se as long as it does not provide the most effective and comprehensive protection of human rights to individuals in Europe. Therefore, the cases of so called "negative crossfertilization", such as the Mihalache $v$ Romania case, do not provide an example of successful application of the method of maintenance of the status quo.

Some guidance can, however, be provided as to the desirable approach in utilising autonomous concepts by the two courts. Firstly, what is required is a careful consideration of the context of the EU law principles in the jurisprudence of the ECtHR, in order to avoid acritical reception and negative cross-fertilization. Secondly, it would require from both courts, particularly the CJEU to maintain, at all times, the minimal level of protection of human rights that is enshrined in the ECHR. That approach derives from the EU Charter, and is fully in line with the commitment of the EU to accede to the ECHR.

\section{References}

Bjorge, E. 2015. Autonomous Concepts, in Domestic Application of the ECHR: Courts as Faithful Trustees. Oxford: Oxford University Press.

Ćeranić, J. 2017. Odgovornost države za naknadu štete pojedincima zbog povrede prava EU - ocena primene režima odgovornosti dvadeset godina nakon presude Francovich. In: Petrović, Z. \& Čolović V. (eds.), Odgovornost za štetu, naknada štete i osiguranje. Beograd/Zrenjanin: Udruženje za odštetno pravo, Institut za uporedno pravo, Pravosudna akademija, pp. 89-102. 
Ćeranić, J. 2009. Ratifikacija Lisabonskog ugovora - Reforma Evropske unije: Bilans i perspektive. Strani pravni život, 3, pp. 7-25.

Ćorić Erić, V. 2013. Odnos Evropskog suda pravde i Evropskog suda za ljudska prava. $\mathrm{PhD}$ thesis. Belgrade: Faculty of Law, University of Belgrade.

Craig, P. 2013. EU Accession to the ECHR: Competence, Procedure and Substance. Fordham International Law Journal, 36(5), pp. 1115-1150.

Defeis, E. F. 2001. Human Rights and The European Union: Who Decides? Possible Conflicts between the European Court of Justice and the European Court of Human Rights. Dickinson Journal of International Law, 19(2), pp. 301-323.

Douglas-Scott, S. 2006. A Tale of Two Courts: Luxemburg, Strasbourg and the Growing European Human Rights Acquis. Common Market Law Review, 43(3), pp. 629-665.

Glas, L. R. \& Krommendijk, J. 2017. From Opinion 2/13 to Avotinš: Recent Developments in the Relationship between the Luxembourg and Strasbourg Court. Human Rights Law Review, 17(3), pp. 567-587.

Ilić, G. 2017. Načelo ne bis in idem u praksi Evropskog suda za ljudska prava. Strani pravni život, 61(3), pp. 21-34.

Kuijer, M. 2020. The challenging relationship between the European Convention on Human Rights and the EU legal order: consequences of a delayed accession. The International Journal of Human Rights, 24 (7), pp. 998-1010. doi: 10.1080/13642987.2018.1535433.

Lach, A. 2017. Effective investigation of crime and the European ne bis in idem principle. Teisés apžvalga Law review, 2(16), pp. 5-16. doi: http://dx.doi.org/10.7220/20294239.16.1.

Lasagni, G. \& Mirandola, S. 2019. The European ne bis in idem at the Crossroads Administrative and Criminal Law. Eucrim, 2, pp. 126-135. doi: https://doi. org/10.30709/ eucrim-2019-009.

Lock, T. 2016. The influence of EU law on Strasbourg doctrines. European Law Review, 41(6), pp. 804-825.

Mahoney, P. 1998. Marvellous Richness of Diversity or Invidious Cultural Relativism. Human Rights Law Journal, 19(1), pp. 1-6.

Matić Bošković, M. \& Kostić, J. 2020. The application of the ne bis in idem related to financial offences in the jurisprudence of the European courts. Nauka, bezbednost, policija, 25(2), pp. 67-77. doi:10.5937/nabepo25-27224.

Matić Bošković, M. 2020. Uređenje procesnih prava osumnjičenih i okrivljenih u pravnim tekovinama Evropske unije. Strani pravni život, 64(1), pp. 29-43.

Milčiuviené, S. 2019. The Influence of the Court of Justice of the European Union on the Issuance of European Arrest Warrants in Lithuania. Baltic Journal of Law \& Politics, 12(2), pp. 97-114.

Mitsilegas, V. 2016. Managing Legal Diversity in Europe's Area of Criminal Justice: The Role of Autonomous Concepts. In: Colson R. \& Field S. (eds.), EU Criminal Justice and the Challenges of Diversity: Legal Cultures in the Area of Freedom Security and Justice. Cambridge: Cambridge University Press, pp. 125-159.

O'Leary, S. 2018. A Tale of Two Cities: Fundamental Rights Protection in Strasbourg and 
Luxembourg. Cambridge Yearbook of European Legal Studies, 20, pp. 3-31. doi: 10.1017/cel.2018.3.

Serneels, C. 2020. 'Unionisation' of the European Court of Human Rights' ne bis in idem jurisprudence: the Case of Mihalache $v$ Romania. New Journal of European Criminal Law, 11(2), pp. 227-239. doi:10.1177/2032284419888291.

Toth, A. G. 1997. The European Union and Human Rights: The Way Forward. Common Market Law Review, 34(3), pp. 491-529.

Van Den Berghe, F. 2010. The EU and Issues of Human Rights Protection: Same Solutions to More Acute Problems?. European Law Journal, 16(2), pp. 112-157.

Weiler, J.H.H. \& Alston, P. 1999. An 'Ever Closer Union' in Need of a Human Rights Policy: The European Union and Human Rights. In: Alston, M. Bustelo, R. \& Heenan, J (eds.), The EU and Human Rights, New York: Oxford University Press, pp. 3-66.

Witte, B. 2018. The European Union in the International System of Human Rights Protection: Solo Singer or Voice in the Choir?. In: Bribosia, E. \& Rorive, I. (eds.), Human Rights Tectonics: Global Dynamics of Integration and Fragmentation. Intersentia, pp. 225-242. doi:10.1017/9781780688060.011.

Ziegler, K. 2016. The Relationship between EU Law and International Law. In: Patterson, D. \& Södersten, A. (eds.), Blackwell Companion to European Union Law and International Law. Hoboken:Wiley-Blackwell, pp. 42-61.

\section{Website references}

Buyse, A. 2013. Accession of EU to ECHR Draft Agreement: Finally Finalised. Available at: www. echrblog/1912/2986, (13. 11. 2020).

Council of the European Union, General Secretariat, Accession of the European Union to the European Convention for the Protection of Human Rights and Fundamental Freedoms (ECHR), Note, Brussels, 20 September 2019 (OR. en), No. 12349/19, Available at: www.statewatch.org/media/documents/news/2019/sep/eu-councilacession-coe-12349-19.pdf, (29. 11.2020).

Douglas-Scott, S. 2014. Opinion 2/13 on EU accession to the ECHR: a Christmas bombshell from the European Court of Justice. Available at: https://verfassungsblog.de/opinion-213eu-accession-echr-christmas-bombshell-european-court-justice-2/, (21. 12. 2020).

European Commission. 2020. The EU's accession to the European Convention on Human Rights: Joint statement on behalf of the Council of Europe and the European Commission. Brussels, 29 September 2020. Available at: https://ec.europa.eu/ commission/presscorner/detail/en/statement_20_1748, (10.11.2020).

European Parliament. 2020. Legislative Train Schedule, Area of Justice and Fundamental Rights, Completion of EU Accession to the ECHR. Available at: www.europarl. europa.eu/legislative-train/theme-area-of-justice-and-fundamental-rights/filecompletion-of-eu-accession-to-the-echr/12-2020, (21. 12. 2020).

Lenaerts, K. \& Gutiérrez-Fons, J. A. 2013. To Say What the Law of the EU Is: Methods of Interpretation and the European Court of Justice. European University, Institute 
Academy of European Law, EUI Working Paper AEL 2013/9. Available at: https:// cadmus.eui.eu/handle/1814/28339, (19. 11. 2020).

Lenearts, K. 2018. Solemn hearing for the opening of the Judicial Year 26 January 2018: The ECHR and the CJEU: Creating Synergies in the Field of Fundamental Rights Protection (Speech), European Court of Human Rights. Available at: https://www. echr.coe.int/Documents/Speech_20180126_Lenaerts_JY_ENG.pdf, (11.11.2020). Lyaskova, K. 2019. Mihalache v Romania [GC], Case Summary. Available at: https://ehrac. org.uk/resources/mihalache-v-romania/, (10.11.2020).

Murphy, C. 2013. On the Rocky Road to Accession: Final Draft of EU's Accession Agreement to ECHR Approved. Available at: http://europeanlawblog.eu/? p=1680, (10.11.2020).

\section{Legal sources and case law}

Opinion 2/13 pursuant to Article 218(11) TFEU, ECLI:EU:C:2014:2454, European Union: Court of Justice of the European Union, 18 December 2014. Available at: https:// www.refworld.org/cases,ECJ,5899f2c74.html, (10. 12. 2020).

The Charter of Fundamental Rights of the European Union 2012/C 326/02, Official Journal of the European Union J C 326, 26.10.2012, pp. 391-407, Official Journal of the European Union C 326, 26.10.2012, pp. 391-407. Available at: https://eur-lex. europa.eu/legal-content/EN/TXT/?uri=CELEX\%3A12012P\%2FTXT, (10. 11.2020).

Convention for the Protection of Human Rights and Fundamental Freedoms, Rome, 4.XI.1950. Available at: https://www.echr.coe.int/Documents/Convention_ENG. pdf, (8. 11.2020).

Protocol No. 16 to the Convention for the Protection of Human Rights and Fundamental Freedoms CETS No. 214. Available at: https://www.coe.int/en/web/conventions/ search-on-treaties/-/conventions/treaty/214, (8.11.2020).

Ministers' Deputies Decisions Cm/Del/Dec(2020)1364/4.3, 15 January 2020. Continuation of the ad hoc terms of reference for the CDDH to finalise the legal instruments setting out the modalities of accession of the European Union to the European Convention on Human Rights. Available at: https://search.coe.int/cm/pages/ result_details.aspx?objectid $=09000016809979 \mathrm{be},(20.11 .2020)$.

Steering Committee for Human Rights (CDDH). 2010. Ad hoc terms of reference concerning accession of the EU to the Convention given to the CDDH by the Ministers' Deputies during their $1085^{\text {th }}$ meeting (26 May 2010). Strasbourg, 3 June 2010. Available at: https://rm.coe.int/steering-committee-for-human-rights-cddh-ad-hoc-terms-ofreference-con/16809c8e22, (20.11.2020).

ECtHR [GC], App nos 24130/11 and 29758/11, A and B v Norway, Judgment, 15 November 2016. Available at: https://hudoc.echr.coe.int/eng\#\{\%22itemid\%22:[\%22001-168972\%22]\}, (6. 11. 2020).

ECtHR [GC], App no 54012/10, Mihalache v Romania, Judgment, 8 July 2019. Available at: https://hudoc.echr.coe.int/spa\#\{\%22itemid\%22:[\%22001-194523\%22]\}, (6. 11. 2020).

EctHR [GC], App. no. 45036/98, Bosphorus Hava Yollari Turizm ve Ticaret AS v. Ireland, Judgement, 30 June 2005, Reports of Judgments and Decisions/Recueil des arrêts 
et décisions 2005-VI.

CJEU, Criminal proceedings against Luca Menci, Judgment of the Court (Grand Chamber) of 20 March 2018, Case C-524/15, ECLI:EU:C:2018:197.

CJEU, Enzo Di Puma v Commissione Nazionale per le Società e la Borsa (Consob), Judgment of the Court (Grand Chamber) of 20 March 2018, Case C-596/16, ECLI:EU:C:2018:192.

CJEU, Garlsson Real Estate SA and others v Commissione Nazionale per le Società e la Borsa (Consob), Judgment of the Court (Grand Chamber) of 20 March 2018, Case C-537/16, ECLI:EU:C:2018:193.

CJEU, Criminal proceedings against Piotr Kossowski, Judgment of the Court (Grand Chamber) of 29 June 2016, (Case C-486/14 ECLI:EU:C:2016:483)

\title{
Dr Vesna B. Ćorić
}

Viši naučni saradnik, Institut za uporedno pravo, Beograd, Srbija

e-mail:v.coric@iup.rs

\section{Dr Ana S. Knežević Bojović}

Naučni saradnik, Institut za uporedno pravo, Beograd, Srbija

e-mail:a.bojovic@iup.rs

\section{AUTONOMNI KONCEPTI I STATUS QUO METOD: U POTRAZI ZA DOSLEDNOM ZAŠTITOM LJUDSKIH PRAVA PRED EVROPSKIM NADNACIONALNIM SUDOVIMA}

\author{
Sažetak
}

Proces pristupanja Evropske unije Evropskoj konvenciji o ljudskim pravima nedavno je ponovo pokrenut. Ipak, u pravnoj nauci se pravilno ukazuje da se radi o komplikovanom i dugotrajnom procesu, dok, sa druge strane, praksa nadnacionalnih evropskih sudova nije međusobno usklađena i u nekim slučajevima za posledicu ima smanjenje obima zaštite ljudskih prava u Evropi. Otuda se javlja potreba da se već sada ispitanju druga rešenja koja mogu doprineti smanjenju neželjenih posledica dugotrajnog pristupanja Evropske unije pomenutoj Konvenciji i doprineti doslednoj i delotvornoj zaštiti ljudskih prava u Evropi. Koristeći se uglavnom dogmatskim metodom, autorke ispituju različite metode predložene u pravnoj teoriji (i primenjene u praksi) sa stanovišta njihovog potencijala da doprinesu delotvornoj zaštiti ljudskih prava, u odsustvu institucionalnih veza između Suda pravde Evropske unije i Evropskog suda za ljudska prava. Autorke potom ukazuju na potrebu da, u primeni metoda zadržavanja statusa quo, koji se trenutno čini najcelishodnijim, dva evropska nadnacionalna suda pribegnu unapređenoj primeni koncepta autonomnih pojmova. One tu potrebu zatim i ilustruju kroz prikaz novije sudske prakse dva navedena suda u odnosu na princip ne bis in idem. U zaključnom delu rada autorke formulišu predloge 
za unapređenje pristupa Suda pravde Evropske unije i Evropskog suda za ljudska prava u razvijanju i formulisanju autonomnih pojmova, u cilju postizanja delotvorne zaštite ljudskih prava u Evropi i pre nego što Evropska unija pristupi Evropskoj konvenciji o ljudskim pravima.

Ključne reči: Evropska unija, Evropska konvencija o ljudskim pravima, nadnacionalni sudovi, autonomni koncepti, ne bis in idem.

Article history:

Received: 4 January 2021

Revised: 19 January 2021

Accepted: 20 January 2021 